Original Scientific Article

\title{
DETERMINATION OF AFLATOXINS AND OCHRATOXIN A IN ANIMAL LIVER USING HPLC-FD METHOD WITH IMMUNOAFFINITY COLUMN CLEAN-UP
}

\author{
Biljana Stojanovska-Dimzoska, Elizabeta Dimitrieska-Stojkovic, Zehra Hajrulai-Musliu, \\ Risto Uzunov, Aleksandra Angeleska, Dean Jankuloski, Katerina Blagoevska \\ Food Institute, Faculty of Veterinary Medicine Skopje, \\ Lazar Pop Trajkov 5-7, 1000 Skopje, R. North Macedonia
}

Received 4 February 2021; Received in revised form 2 April 2021; Accepted 5 April 2021

\begin{abstract}
Analytical methods based on immunoaffinity column clean-up and quantitative determination with liquid chromatography-fluorescence detection were used to determine aflatoxins and ochratoxin A in liver samples. The validation of the procedures was performed. The linearity of the methods was checked, and a good coefficient of correlation was found for all aflatoxins and OTA as well. The LOD and LOQ were acceptable: $0.003 \mu \mathrm{g} / \mathrm{kg}$ and $0.009 \mu \mathrm{g} / \mathrm{kg}$ for AFB $; 0.001 \mu \mathrm{g} / \mathrm{kg}$ and $0.005 \mu \mathrm{g} / \mathrm{kg}$ for $\mathrm{AFB}_{2} ; 0.006 \mu \mathrm{g} / \mathrm{kg}$ and $0.020 \mu \mathrm{g} / \mathrm{kg}$ for $\mathrm{AFG}_{;} ; 0.007 \mu \mathrm{g} / \mathrm{kg}$ and $0.022 \mu \mathrm{g} / \mathrm{kg}$ for AFG $; 0.08 \mu \mathrm{g} / \mathrm{kg}$ and $0.27 \mu \mathrm{g} / \mathrm{kg}$ for OTA. The results for the repeatability estimated by the relative standard deviation (RSD) were satisfactory and the obtained values were in the acceptable range (1.97-14.41\% for all aflatoxins and $3.76-8.31 \%$ for OTA) at three proposed concentration levels. $\mathrm{RSD}_{\mathrm{R}}$ values showed acceptable correlation between two analysts for all four aflatoxins and OTA. The RSD $\mathrm{R}_{\mathrm{R}}$ values were as followed: $2.37 \%$ and $5.60 \%$ for $\mathrm{AFB}_{1}, 6.71 \%$ and $8.78 \%$ for $\mathrm{AFB}_{2}, 4.40 \%$ and $7.00 \%$ for $\mathrm{AFG}_{1}$ and $10.30 \%$ and $13.91 \%$ for $\mathrm{AFG}_{2}$ (for the first and second analyst, respectively). The $\mathrm{RSD}_{\mathrm{R}}$ values for OTA were $4.91 \%$ and $3.15 \%(1 \mu \mathrm{g} / \mathrm{kg}) ; 3.76 \%$ and $4.12 \%(5 \mu \mathrm{g} / \mathrm{kg})$ and $8.31 \%$ and $8.21 \%(10 \mu \mathrm{g} / \mathrm{kg})$. The mean recovery for total aflatoxins and OTA were $78.10 \%$ and $93.34 \%$, respectively. All validation parameters were in accordance to European legislation. They indicate that the proposed analytical procedures are suitable and they could be methods of choice for the determination of aflatoxins and OTA in liver samples.
\end{abstract}

Key words: aflatoxins, ochratoxin A, HPLC-FD, liver samples, validation

\section{INTRODUCTION}

Mycotoxins are secondary metabolites produced by various genera of molds (Aspergillus, Penicillium, Fusarium). Cereals contaminated with mycotoxins, when are ingested by animals, can cause a toxic response (mycotoxicosis) resulting with carcinogenic, estrogenic, teratogenic or immunosuppressive effects (1). Consumption of a mycotoxin-contaminated diet may have direct consequences on animal health and economic

Corresponding author: Dr. Biljana Stojanovska-Dimzoska, $\mathrm{PhD}$ E-mail address: bsdimzoska@fvm.ukim.edu.mk

Present address: Food Institute, Faculty of Veterinary Medicine Skopje, Lazar Pop Trajkov 5-7, 1000 Skopje, R. North Macedonia

Phone: ++389 23240745

Copyright: (C) 2021 Stojanovska-Dimzoska B. This is an open-access article published under the terms of the Creative Commons Attribution

License which permits unrestricted use, distribution, and reproduction in any medium, provided the original author and source are credited. Competing Interests: The authors have declared that no competing interests exist.

Available Online First: 12 April 2021

Published on: 15 October 2021

https://doi.org/10.2478/macvetrev-2021-0017 impact as well. This includes reduced weight gain and reproductive capacities, feed refusal and poor feed conversion, less meat and egg production, increased disease incidence (due to immunesuppression) and lower productivity (1-2).

Due to modern laboratory methods and a growing interest in this field of research, more than 300 mycotoxins have been differentiated so far. Among them, aflatoxins, especially aflatoxin $\mathrm{B}_{1}\left(\mathrm{AFB}_{1}\right)$ exhibits the highest toxicity and carcinogenicity and it can be found as a residue in animal liver after ingestion of contaminated feed (3). International Agency for Research on Cancer (IARC) made classification of naturally occurring $\mathrm{AFB}_{1}$ as carcinogenic to humans (Group 1). Ochratoxin A (OTA) contamination is also a significant public food safety concern due to accumulation of its residues in animal tissues, predominant in kidney, but also in liver, muscle and fat. OTA is involved in the etiology of Balkan Endemic Nephropathy 
(BEN), a human disease characterized by progressive renal fibrosis and by tumors of the urinary tract. IARC made classification of OTA as possibly carcinogenic to humans (Group 2B). Mycotoxin content in food and feed is regulated by legislation worldwide (Commission Regulation 466/2001, 2174/2003, 1881/2006 for food and Commission Directive 2002/32 and 2003/100 for feed). The Commission of European Communities has not set maximum residue limits (MRL) for mycotoxins in animal tissues, but it recommends that OTA levels should be reduced to below $5 \mathrm{ng} / \mathrm{kg}$ of body weight per day. Several countries have enforced their own regulation for animal origin foodstuff. They are vary in the range of $1-10 \mu \mathrm{g} / \mathrm{kg}$ for pork and bovine meat (4).

Different analytical methods are used for aflatoxins and OTA analysis which are mainly based on liquid chromatography with fluorescence detection and previous clean-up step. Most of them are greatly improved with the commercial availability of immunoaffinity columns (IAC), which are simple and rapid to use, also provide good recovery values. Several articles report the use of these methods for aflatoxins $(5,6,7)$ and OTA $(8,9$, $10)$ in food and feed. To the best of our knowledge, very few reports give methods for determination of aflatoxins $(11,12)$ and OTA $(13,14,15)$ in food of animal origin. Having in mind the significant health risks in human and animals associated with the presence of aflatoxins and OTA in food and feed, it is important to establish an analytical method for the determination of aflatoxins and OTA in food of animal origin.

The purpose of this work was to provide and validate a precise and reliable analytical methods for determination of aflatoxins and OTA in animal liver using simple immunoaffinnity column clean-up and liquid chromatography with fluorescence detection. Postcolumn bromination (Kobra ${ }^{\circledR}$ cell) was used in order to determine aflatoxins. The validation procedure was performed according to European Decision 2002/657/EC (16) and Regulation 401/2006/EC amending mycotoxins (17). Also, the aim of this study was to carry out an overview for presence of aflatoxins and OTA in animal liver samples taken from slaughterhouses in Republic of North Macedonia over the period of six years (2015-2020). To the best of our knowledge, such investigation has not be done so far in our country. This research would provide a screening of the natural occurrence of aflatoxins and OTA in animal tissues, having in mind its potential health hazard for human consumption.

\section{MATERIAL AND METHODS}

\section{Apparatus}

HPLC analysis for aflatoxins were performed with a Perkin Elmer (PE) chromatographic system equipped with binary pump (PE LC-250), manual injector (PE Rheodyne 7125) and fluorescence detector (PE LC-240). Aflatoxins were separated on RP C18 column (250 mm x $4.6 \mathrm{~mm}$, $5 \mu \mathrm{m})$. The mobile phase consisted mixture of water:acetonitrile:methanol $\quad(600: 350: 50, \quad V / V / V)$ with addition of $119 \mathrm{mg} \mathrm{KBr}$ and $350 \mathrm{ml} 4 \mathrm{~N} \mathrm{HNO}_{3}$ ). The flow rate was $1 \mathrm{ml} / \mathrm{min}$ and the injection volume was $100 \mathrm{ml}$. The detection was carried out at $\kappa_{\mathrm{ex}}=360 \mathrm{~nm}$ and $\kappa_{\mathrm{em}}=440 \mathrm{~nm}$.

HPLC system (Waters Alliance) was used for determination of OTA (Waters separation module e2695 and Waters fluorescence detector 2475). An analytical column RP C18 (150 mm x $4.6 \mathrm{~mm}, 5 \mu \mathrm{m}$ ) was used with mobile phase consisting of acetonitrile:water:acetic acid mixture (99:99:2, $V / V / V)$. Flow rate was $1 \mathrm{ml} / \mathrm{min}$. The detection was carried out at $\Lambda_{\mathrm{ex}}=333 \mathrm{~nm}$ and $\Lambda_{\mathrm{em}}=460 \mathrm{~nm}$.

\section{Reagents and standard solutions}

HPLC reagents (methanol, acetonitrile, water) and chemicals (benzene, $\mathrm{KBr}, \mathrm{NaCl}$, dichloromethane, ethyl acetate, citric acid, diatomaceous earth, anhydrous $\mathrm{Na}_{2} \mathrm{SO}_{4}, 65 \% \mathrm{HNO}_{3}$, $85 \%$ phosphoric acid, glacial acetic acid, $2 \mathrm{M} \mathrm{NaCl}$, $0.5 \mathrm{M} \mathrm{H}_{3} \mathrm{PO}_{4}$, phosphorus buffer 7.0 or PBS buffer) were purchased from Merck (Darmstadt, Germany) or Sigma-Aldrich (USA). For clean-up step immunoaffinity columns Aflaprep and Ochraprep (R-Biopharm Rhône, Glasgow, Scotland) were used. As a standard, aflatoxins mix (AFB $982 \mathrm{ng} / \mathrm{ml}$, $\mathrm{AFB}_{2} 284 \mathrm{ng} / \mathrm{ml}, \mathrm{AFG}_{1} 1034 \mathrm{ng} / \mathrm{ml}, \mathrm{AFG}_{2} 333 \mathrm{ng} / \mathrm{ml}$ ) (Supelco, Sigma-Aldrich, USA) was used and OTA standard with concentration of $50 \mu \mathrm{g} / \mathrm{ml}$ (Supelco, Sigma-Aldrich, USA) was used too.

Aflatoxins mix stock solution (AFB $100 \mathrm{ng} / \mathrm{ml}$, $\mathrm{AFB}_{2} 28.4 \mathrm{ng} / \mathrm{ml}, \mathrm{AFG}_{1} 103.4 \mathrm{ng} / \mathrm{ml}, \mathrm{AFG}_{2} 33.3 \mathrm{ng} / \mathrm{ml}$ ) was prepared from the aflatoxins mix standard, dissolving aliquot in a volumetric amber flask of $10 \mathrm{ml}$. Seven working standard solution (for $\mathrm{AFB}_{1}$ in a range $0.25-15.00 \mathrm{ng} / \mathrm{ml}$; for $\mathrm{AFB}_{2}$ in a range 0.071 $4.260 \mathrm{ng} / \mathrm{ml}$; for $\mathrm{AFG}_{1}$ in a range $0.258-15.510 \mathrm{ng} / \mathrm{ml}$ and for $\mathrm{AFG}_{2}$ in a range $0.083-4.990 \mathrm{ng} / \mathrm{ml}$;) were prepared from the stock solution in volumetric amber flasks of $5 \mathrm{ml}$. All working standards were kept in a refrigerator at $2-8{ }^{\circ} \mathrm{C}$.

Aliquot of OTA standard $(50 \mu \mathrm{g} / \mathrm{ml})$ was used to prepare an OTA stock solution with concentration 
of $5.0 \mu \mathrm{g} / \mathrm{ml}$ using salinized glass vial in order to keep the mycotoxin in the solution. It was used for preparation of intermediate solutions with concentration of $1000 \mathrm{ng} / \mathrm{ml}$ and $100 \mathrm{ng} / \mathrm{ml}$. Seven working solution in range $0.10-20 \mathrm{ng} / \mathrm{ml}$ were obtained from the intermediate solution at $100 \mathrm{ng} / \mathrm{ml}$. All working standards were dissolved in filtrated mobile phase and were kept in a refrigerator at $2-8^{\circ} \mathrm{C}$.

\section{Samples}

During validation procedure, samples of animal liver were used, purchased in the local market, intended for human consumption. For validation purpose, samples were spiked with $\mathrm{AFB}_{1}$ working standard solution prior to the extraction, at three concentration levels $(0.10,0.25$ and $0.50 \mu \mathrm{g} / \mathrm{kg})$. For OTA spiking, also three concentration levels were analyzed (1.0, 5.0 and $10.0 \mu \mathrm{g} / \mathrm{kg})$. Those portions of standards were applied to a measured liver sample and they were kept for approximately $30 \mathrm{~min}$. to addition of the extraction solvent.

For screening purpose, animal liver samples were taken from slaughterhouses or brought by food inspectors from all over the country. They were stored in specimen containers at $-18{ }^{\circ} \mathrm{C}$ until analysis.

\section{Analytical procedure}

The extraction and purification of aflatoxins from liver samples was done according to our reference (12) and modified AOAC procedure (18). HPLC-FD detection was performed according to ISO 16050:2003 standard (19). Homogenized liver sample $(50.0 \mathrm{~g})$ was mixed well with $5 \mathrm{ml}$ of $20 \%$ citric acid and $10 \mathrm{~g}$ diatomaceous earth. The mixture was extracted with $100 \mathrm{ml}$ dichloromethane on shaker for $30 \mathrm{~min}$. Then, the mixture was filtered and dried by addition of $5 \mathrm{~g}$ anhydrous $\mathrm{Na}_{2} \mathrm{SO}_{4}$ and filtered again. Twenty (20) $\mathrm{ml}$ of the filtrate was evaporated until dryness at $60^{\circ} \mathrm{C}$. Dry residue was dissolved in $5 \mathrm{ml}$ of methanol and the solution was mixed with $25 \mathrm{ml}$ of phosphorus buffer ( $\mathrm{pH} 7.0$ ). The solution was mixed well and filtered again through microfiber filter. The entire sample was applied onto the immunoaffinity column. Ten (10) $\mathrm{ml}$ of water was used for the washing step. Aflatoxins were eluted with $1 \mathrm{ml}$ of methanol. The elution step was repeated one more time with $1 \mathrm{ml}$ of water. Then, $100 \mu \mathrm{l}$ of methanol-water solution was used for further analysis.

The process for extraction and purification of OTA in animal tissues was done according to modified method (14). Volume of $10 \mathrm{ml}$ extraction solvent (dichlormethane:ethyl acetate (1:3)) and $10 \mathrm{ml}$ $0.5 \mathrm{M} \mathrm{H}_{3} \mathrm{PO}_{4}$ in $2 \mathrm{M} \mathrm{NaCl}$ was added to $25 \mathrm{~g}$ tissue sample and blended or homogenized in a baker for a few minutes. Then the samples were put for $30 \mathrm{~min}$ on a horizontal shaker. The mixture was filtered using filter paper. An aliquot of the filtrate $(10 \mathrm{ml})$ was evaporated to dryness. Dry residue was dissolved in $2 \mathrm{ml}$ methanol and $30 \mathrm{ml}$ PBS buffer. Then the solution was filtered again using microfiber filter. Twenty (20) $\mathrm{ml}$ of the filtrate passed through the immunoaffinity column. Twenty (20) $\mathrm{ml}$ of water was use for washing step. OTA was eluted with $4 \mathrm{ml}$ of methanol in a vial. The solution was evaporated under of stream of nitrogen until dryness. The dry residue was re-dissolved in $1 \mathrm{ml}$ of mobile phase for further chromatographic analysis.

\section{Validation procedure}

The validation procedure was achieved in agreement to general Decision 2002/657/EC (16) and Regulation 401/2006/EC (17) which is related to mycotoxins. Seven working standard solutions were used for the linearity test in the following range: for $\mathrm{AFB}_{1}(0.25-15.00 \mathrm{ng} / \mathrm{ml})$, for $\mathrm{AFB}_{2}(0.071-4.260 \mathrm{ng} / \mathrm{ml})$, for $\mathrm{AFG}_{1}(0.258-15.510 \mathrm{ng} / \mathrm{ml})$, for $\mathrm{AFG}_{2}(0.083$ $4.990 \mathrm{ng} / \mathrm{ml})$ and OTA $(0.1-20.0 \mathrm{ng} / \mathrm{ml})$.

The limit of detection (LOD) was calculated as $3.3 \times \mathrm{SD} /$ slope, where the slope was determined from the calibration curve. Standard deviation (SD) was based on measurement of analytical background response of 10 blank samples. The limit of quantification (LOQ) was calculated as $10 \mathrm{xSD} /$ slope in the same way as LOD calculation.

Because the certified reference material was not available, recovery was determined as a part of trueness of the method. Method for standard addition at the following fortified concentration levels was applied: for $\mathrm{AFB}_{1}(0.10,0.25$ and $0.50 \mu \mathrm{g} / \mathrm{kg})$, for $\mathrm{AFB}_{2}(0.028,0.071$ and $0.142 \mu \mathrm{g} / \mathrm{kg})$, for $\mathrm{AFG}_{1}(0.103,0.258$ and $0.517 \mu \mathrm{g} / \mathrm{kg})$, for $\mathrm{AFG}_{2}$ $(0.033,0.083$ and $0.166 \mu \mathrm{g} / \mathrm{kg})$ and for OTA (1.0, 5.0 and $10.0 \mu \mathrm{g} / \mathrm{kg}$ ), using liver sample which was free from aflatoxins and OTA (previous determined with HPLC-FD). The analysis was performed with six replicates at each level of fortification.

Repeatability was predicted through the standard deviation and relative standard deviation, using the data of the recovery measurements. Within-laboratory reproducibility of the method was determined in the same fortified concentration levels with six replicates at each level. Those steps were repeated in different days, using the same methods and the same apparatus. Two different analysts performed the analysis. 
The expanded measurement uncertainty $U$ at the proposed concentration level $(0.50 \mu \mathrm{g} / \mathrm{kg}$ and $5.0 \mu \mathrm{g} / \mathrm{kg}$ for $\mathrm{AFB}_{1}$ and OTA, respectively) was calculated from the within-laboratory reproducibility and other factors: standard solution, pipettes that we used and balance as well, using coverage factor 2 (95\% confidence level). All of those factors were adjusted as a percentage according to NIST Uncertainty Guideline (20).

\section{RESULTS}

Seven-point calibration curves were linear in the suggested concentration range for all four aflatoxins and OTA as well, with satisfactory coefficient of correlation $\left(\mathrm{R}^{2}>0.998\right)$. The methods were appropriate over the tested concentration range, having in mind that there is no requirement for the maximum permitted level of aflatoxins and OTA in liver within European legislation.

The chromatograms obtained when IAC clean-up procedure was performed, were clean, with flat baseline, no matrix effects and practically no impurity and unidentified peaks, as can be seen in Fig. 1 and Fig. 2.

The limit of detection was acceptable (for $\mathrm{AFB}_{1}$ it was $0.003 \mu \mathrm{g} / \mathrm{kg}$; for $\mathrm{AFB}_{2} 0.001 \mu \mathrm{g} / \mathrm{kg}$, for $\mathrm{AFG}_{1}$ $0.006 \mu \mathrm{g} / \mathrm{kg}$ and for $\mathrm{AFG}_{2} 0.007 \mu \mathrm{g} / \mathrm{kg}$ ). Limit of quantification was also satisfactory (for $\mathrm{AFB}_{1}$ it was $0.009 \mu \mathrm{g} / \mathrm{kg}$; for $\mathrm{AFB}_{2} 0.005 \mu \mathrm{g} / \mathrm{kg}$, for $\mathrm{AFG}_{1}$ $0.02 \mu \mathrm{g} / \mathrm{kg}$ and for $\mathrm{AFG}_{2} 0.022 \mu \mathrm{g} / \mathrm{kg}$ ). LOD and LOQ values for OTA were found $0.08 \mu \mathrm{g} / \mathrm{kg}$ and $0.27 \mu \mathrm{g} / \mathrm{kg}$, respectively.

A

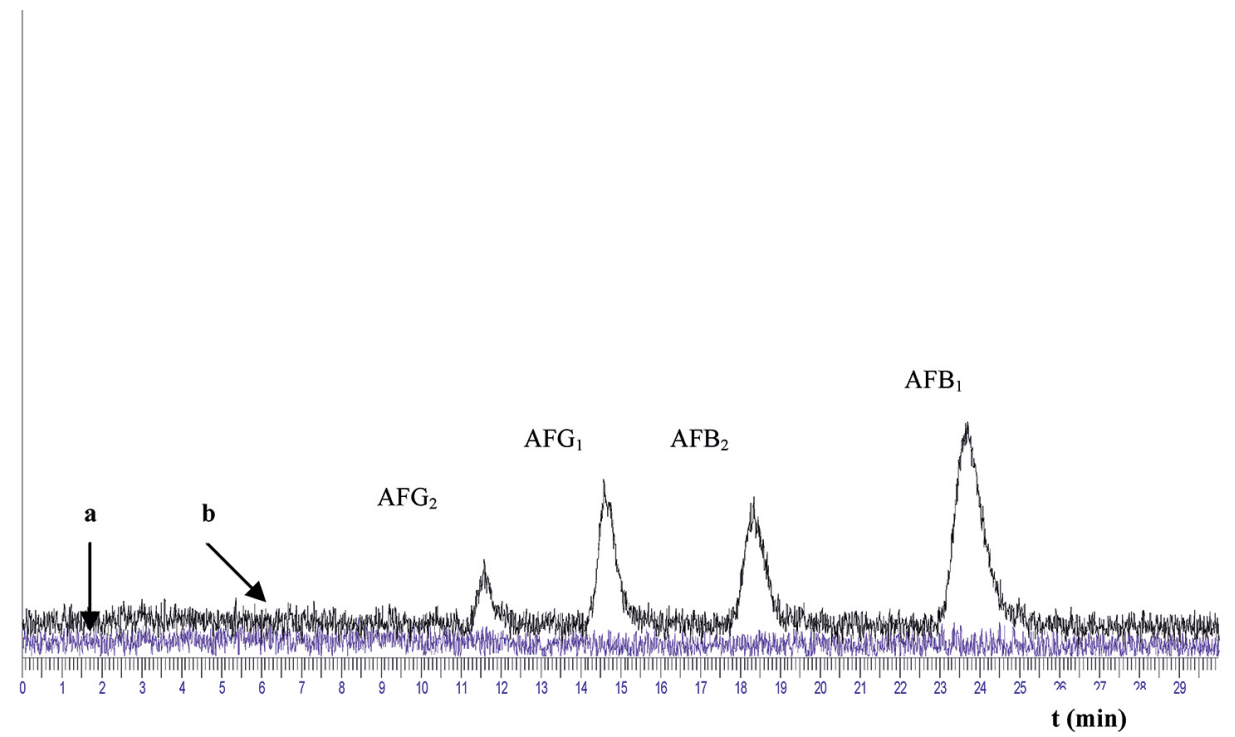

Figure 1. Chromatograms of (a) blank liver sample and (b) fortified liver sample with concentration of $\mathrm{AFB}_{1}$ $0.50 \mu \mathrm{g} / \mathrm{kg} ; \mathrm{AFB}_{2} 0.142 \mu \mathrm{g} / \mathrm{kg} ; \mathrm{AFG}_{1} 0.517 \mu \mathrm{g} / \mathrm{kg}$ and $\mathrm{AFG}_{2} 0.166 \mu \mathrm{g} / \mathrm{kg}$

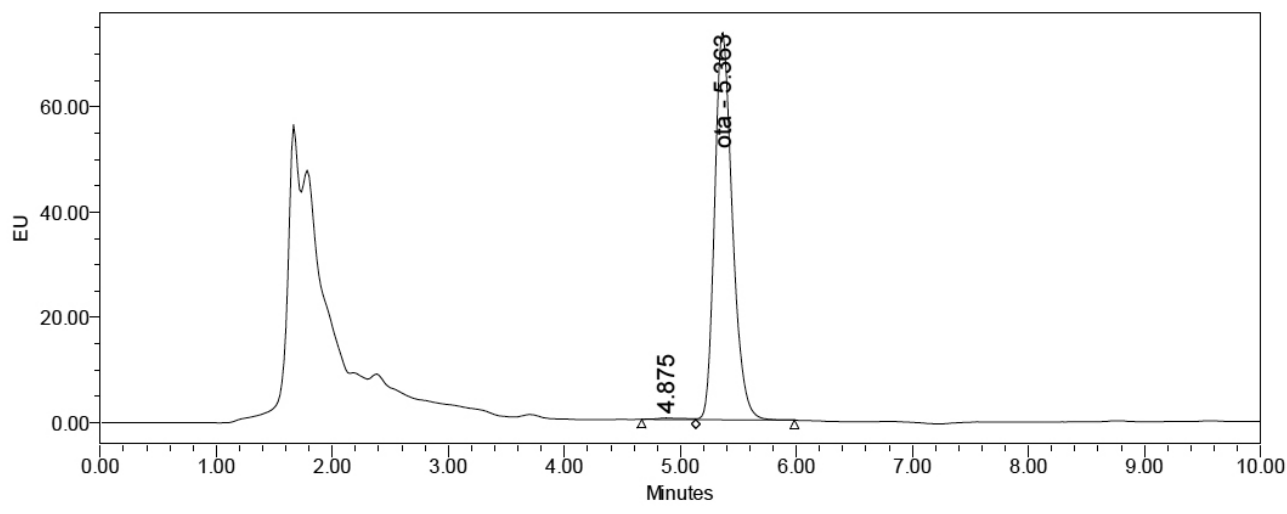

Figure 2. Chromatogram of fortified liver sample with concentration of OTA $5.0 \mu \mathrm{g} / \mathrm{kg}$ 
The results for the repeatability estimated by the relative standard deviation $\left(\mathrm{RSD}_{\mathrm{r}}\right)$ are presented in Table 1 at three proposed concentration levels for all four aflatoxins. Accuracy and precision results for OTA are presented in Table 2. The results for the recovery are given in the same Table 1 and Table 2 for aflatoxins and OTA, respectively.

Table 1. Repeatability, estimated by relative standard deviation $\left(\mathrm{RSD}_{\mathrm{r}}\right)$ for aflatoxins

\begin{tabular}{|c|c|c|c|c|c|c|c|}
\hline & $\begin{array}{c}\text { Spiked } \\
\text { concentration } \\
\text { level }(\mu \mathrm{g} / \mathrm{kg})\end{array}$ & $\begin{array}{c}\text { Determined } \\
\text { concentration } \\
\text { level }(\mu \mathrm{g} / \mathrm{kg})\end{array}$ & $\mathrm{SD}_{\mathrm{r}}{ }^{*}$ & $\operatorname{RSD}_{\mathrm{r}}(\%)$ & $\begin{array}{c}\text { Recovery } \\
(\%)\end{array}$ & $\begin{array}{l}\text { Mean } \\
\text { recovery } \\
(\%)\end{array}$ & $\begin{array}{l}\text { Mean recovery } \\
\text { (\%) for total } \\
\text { aflatoxins }\end{array}$ \\
\hline \multirow{3}{*}{$\mathbf{A F B}_{1}$} & 0.100 & 0.085 & 0.008 & 9.967 & 84.500 & \multirow{3}{*}{89.630} & \multirow{12}{*}{$78.100 \%$} \\
\hline & 0.250 & 0.253 & 0.005 & 1.976 & 101.200 & & \\
\hline & 0.500 & 0.416 & 0.010 & 2.376 & 83.200 & & \\
\hline \multirow{3}{*}{$\mathbf{A F B}_{2}$} & 0.028 & 0.025 & 0.003 & 11.054 & 88.730 & \multirow{3}{*}{90.130} & \\
\hline & 0.071 & 0.067 & 0.004 & 5.328 & 94.360 & & \\
\hline & 0.142 & 0.124 & 0.008 & 6.716 & 87.320 & & \\
\hline \multirow{3}{*}{$\mathbf{A F G}_{1}$} & 0.103 & 0.077 & 0.007 & 8.867 & 74.270 & \multirow{3}{*}{85.030} & \\
\hline & 0.258 & 0.236 & 0.025 & 10.803 & 91.290 & & \\
\hline & 0.517 & 0.463 & 0.020 & 4.408 & 89.550 & & \\
\hline \multirow{3}{*}{$\mathbf{A F G}_{2}$} & 0.033 & 0.011 & 0.002 & 14.415 & 33.930 & \multirow{3}{*}{47.610} & \\
\hline & 0.083 & 0.040 & 0.004 & 10.430 & 48.070 & & \\
\hline & 0.166 & 0.101 & 0.010 & 10.300 & 60.840 & & \\
\hline
\end{tabular}

Table 2. Repeatability, estimated by relative standard deviation $\left(\mathrm{RSD}_{\mathrm{r}}\right)$ for OTA

\begin{tabular}{cccccc}
\hline & $\begin{array}{c}\text { Spiked } \\
\text { concentration } \\
\text { level }(\boldsymbol{\mu g} / \mathbf{k g})\end{array}$ & $\begin{array}{c}\text { Determined } \\
\text { concentration } \\
\text { level }(\boldsymbol{\mu g} / \mathbf{k g})\end{array}$ & $\mathbf{S D}_{\mathbf{r}}{ }^{*}$ & RSD $_{\mathbf{r}}(\boldsymbol{\%})$ & Recovery $(\%)$ \\
\hline \multirow{2}{*}{ OTA } & 1.0 & 0.81 & 0.04 & 4.91 & 80.83 \\
& 5.0 & 5.18 & 0.20 & 3.76 & 103.63 \\
\hline $\mathrm{n}^{*}=6$ & 10.0 & 9.56 & 0.79 & 8.31 & 95.57 \\
\hline
\end{tabular}

Table 3. Within-laboratory reproducibility, estimated by standard deviation $\left(\mathrm{SD}_{\mathrm{R})}\right.$ and relative standard deviation $\left(\mathrm{RSD}_{\mathrm{R}}\right)$ for aflatoxins

\begin{tabular}{|c|c|c|c|}
\hline & & I analyst (day 1) & II analyst (day 2) \\
\hline \multirow{4}{*}{$\begin{array}{l}\text { Spiked } \\
\text { concentration } \\
\text { level }(\mu \mathrm{g} / \mathrm{kg})\end{array}$} & $\mathrm{AFB}_{1}$ & 0.500 & 0.500 \\
\hline & $\mathrm{AFB}_{2}$ & 0.142 & 0.142 \\
\hline & $\mathrm{AFG}_{1}$ & 0.517 & 0.517 \\
\hline & $\mathrm{AFG}_{2}$ & 0.166 & 0.166 \\
\hline \multirow{4}{*}{$\begin{array}{l}\text { Determined } \\
\text { concentration } \\
\text { level }(\mu \mathrm{g} / \mathrm{kg})\end{array}$} & $\mathrm{AFB}_{1}$ & 0.416 & 0.430 \\
\hline & $\mathrm{AFB}_{2}$ & 0.124 & 0.125 \\
\hline & $\mathrm{AFG}_{1}$ & 0.463 & 0.465 \\
\hline & $\mathrm{AFG}_{2}$ & 0.101 & 0.108 \\
\hline \multirow{4}{*}{$\begin{array}{l}\mathrm{SD}_{\mathrm{R}}{ }^{*} \\
\mathrm{n}^{*}=6\end{array}$} & $\mathrm{AFB}_{1}$ & 0.010 & 0.024 \\
\hline & $\mathrm{AFB}_{2}$ & 0.008 & 0.011 \\
\hline & $\mathrm{AFG}_{1}$ & 0.020 & 0.033 \\
\hline & $\mathrm{AFG}_{2}$ & 0.010 & 0.015 \\
\hline \multirow{4}{*}{$\operatorname{RSD}_{\mathrm{R}}(\%)$} & $\mathrm{AFB}_{1}$ & 2.376 & 5.609 \\
\hline & $\mathrm{AFB}_{2}$ & 6.716 & 8.781 \\
\hline & $\mathrm{AFG}_{1}$ & 4.408 & 7.067 \\
\hline & $\mathrm{AFG}_{2}$ & 10.300 & 13.910 \\
\hline \multirow{4}{*}{ Recovery (\%) } & $\mathrm{AFB}_{1}$ & 83.200 & 86.000 \\
\hline & $\mathrm{AFB}_{2}$ & 87.320 & 88.020 \\
\hline & $\mathrm{AFG}_{1}$ & 89.550 & 89.940 \\
\hline & $\mathrm{AFG}_{2}$ & 60.840 & 65.060 \\
\hline
\end{tabular}


Table 4. Within-laboratory reproducibility, estimated by standard deviation $\left(\mathrm{SD}_{\mathrm{R})}\right.$ and relative standard deviation $\left(\mathrm{RSD}_{\mathrm{R}}\right)$ for OTA

\begin{tabular}{lcccccc}
\hline & \multicolumn{3}{c}{ I analyst (day 1) } & \multicolumn{3}{c}{ II analyst (day 2) } \\
\cline { 2 - 7 } & $\mathbf{1 . 0} \boldsymbol{\mu} \mathbf{g} / \mathbf{k g}$ & $\mathbf{5 . 0} \boldsymbol{\mu g} / \mathbf{k g}$ & $\mathbf{1 0 . 0} \boldsymbol{\mu g} / \mathbf{k g}$ & $\mathbf{1 . 0} \boldsymbol{\mu g} / \mathbf{k g}$ & $\mathbf{5 . 0} \boldsymbol{\mu g} / \mathbf{k g}$ & $\mathbf{1 0 . 0} \boldsymbol{\mu g} / \mathbf{k g}$ \\
\hline Mean & 0.81 & 5.18 & 9.56 & 0.78 & 4.98 & 9.34 \\
concentration & 0.04 & 0.20 & 0.79 & 0.03 & 0.31 & 1.04 \\
STD (n*=6) & 4.91 & 3.76 & 8.31 & 3.15 & 4.12 & 8.21 \\
RSD $_{\mathbf{R}}(\%)$ & 80.93 & 103.63 & 95.57 & 78.00 & 99.60 & 93.40 \\
Recovery\% & & & & & & \\
\hline
\end{tabular}

In Table 3 the results for the within-laboratory reproducibility expressed with the standard deviation $\left(\mathrm{SD}_{\mathrm{R}}\right)$ and the relative standard deviation $\left(\mathrm{RSD}_{\mathrm{R}}\right)$ are given. $\mathrm{RSD}_{\mathrm{R}}$ values results show adequate correlation in all four aflatoxins. For $\mathrm{AFB}_{1} \mathrm{RSD}_{\mathrm{R}}$ values were $2.37 \%$ (for the first analyst) and $5.60 \%$ (for the second), for $\mathrm{AFB}_{2}$ values were $6.71 \%$ and $8.78 \%$, for $\mathrm{AFG}_{1}$ values were $4.4 \%$ and $7.0 \%$ and for $\mathrm{AFG}_{2}$ values were $10.30 \%$ and $13.91 \%$, respectively.
Reproducibility results for two days for OTA are demonstrated in Table 4. Within-laboratory reproducibility for OTA also show good correlation between two days $(4.91 \%$ and $3.15 \%$ for the concentration level of $1.0 \mu \mathrm{g} / \mathrm{kg} ; 3.76 \%$ and $4.12 \%$ for the concentration level of $5.0 \mu \mathrm{g} / \mathrm{kg}$ and $8.31 \%$ and $8.21 \%$ for the concentration level of $10.0 \mu \mathrm{g} / \mathrm{kg}$ ).

The stability of the method was approved following the recovery over a period of one year. The values obtained for recoveries are presented in Fig. 3 and Fig. 4.

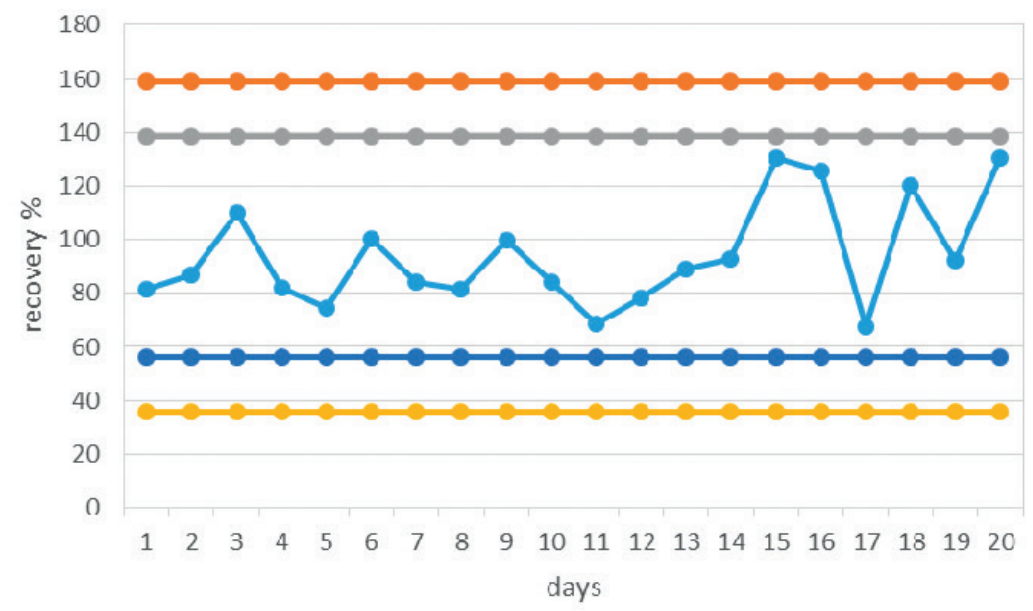

Figure 3. Shewhart control chart for $\mathrm{AFB}_{1}$ (spiking level $0.50 \mu \mathrm{g} / \mathrm{kg}$ )

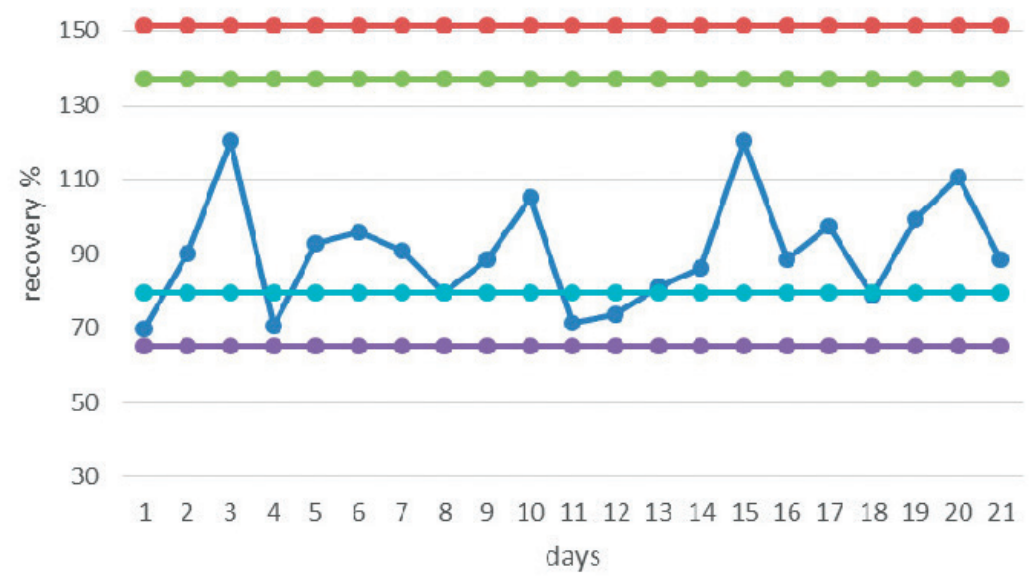

Figure 4. Shewhart control chart for OTA (spiking level $5 \mu \mathrm{g} / \mathrm{kg}$ ) 


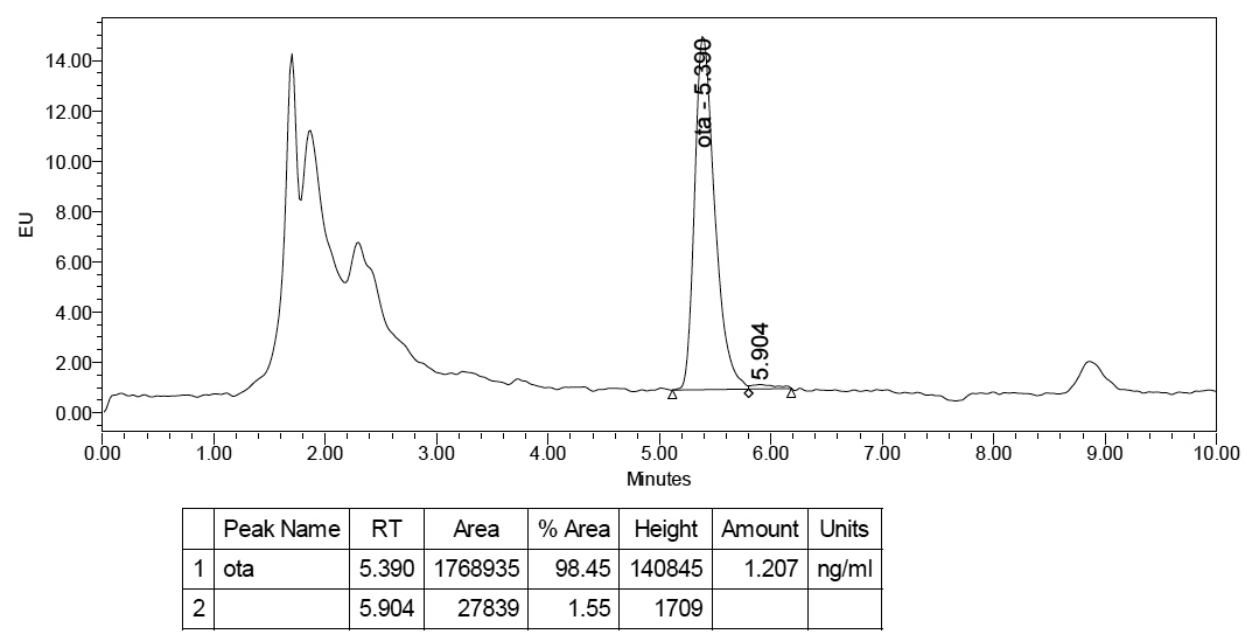

Figure 5. Chromatogram of liver sample with concentration of OTA $0.86 \mu \mathrm{g} / \mathrm{kg}$ (dilution factor is 1.4 )

The measurement uncertainties determined at the proposed concentration level $(0.50 \mu \mathrm{g} / \mathrm{kg}$ for $\mathrm{AFB}_{1}$ and $5.0 \mu \mathrm{g} / \mathrm{kg}$ for OTA) were $15.50 \%$ and $11.26 \%$ for $\mathrm{AFB}_{1}$ and OTA, respectively.

The monitoring of presence of aflatoxins and OTA in animal liver samples was conducted over a period of six years (2015-2020). In thirty seven (37) samples out of 297 OTA was present in concentration range of $0.130-0.922 \mu \mathrm{g} / \mathrm{kg}$. Most of the samples were with OTA concentration below LOD. No one sample was found for presence of aflatoxins. Chromatogram of liver sample with concentration of OTA $0.86 \mu \mathrm{g} / \mathrm{kg}$ is presented on Fig. 5 .

\section{DISCUSSION}

Linearity of the methods with high coefficients of correlation demonstrated reliable results. As can be seen in Fig. 1, Fig. 2 and Fig. 5 there is no potential risk of interfering compounds around selected mycotoxins. This is a due to the IAC selectivity. The columns which are considered to be state-of-the-art in the field of analytical chemistry, contained a gel suspension of monoclonal antibody specific to the toxin of interest. Spiked blank liver sample showed good peaks separation, specific for preferred mycotoxin (Fig. 1). Hence, taking into account the characteristics of IAC, the selectivity and specificity were recognized to be satisfactory for bought methods. We compared some studies $(14,15,21,22)$ with the methods we worked on, and our study showed efficiency and appropriateness for detection of the very low levels for determined mycotoxins (low LOD and LOQ values).
All results obtained from the validation procedure were suitable for evaluation according to the criteria $(16,17)$. Our results for repeatability, determined by $\mathrm{RSD}_{\mathrm{r}}$ (Table 1 and Table 2) were in the acceptable range $(1.97-14.45 \%$ for all aflatoxins and $3.76-8.31 \%$ for OTA) according to the benchmark (mean value for $\mathrm{RSD}_{\mathrm{r}}$ shall not exceed $20 \%$ ). Recovery values as a part of trueness, were satisfactory and in accordance to European legislation (2002/657/EC) and performance criteria set up in Commission Regulation 401/2006. They were in range of $47.61-90.13 \%$ as a recovery for individually aflatoxins, or as mean recovery for total aflatoxins (78.10\%). For OTA, recovery values were in the range of $80.83-103.63 \%$ for three concentration levels of determination. As reported by regulation (16), data corrected with the recovery are only acceptable when they fall within the range $-50 \%$ to $+20 \%$ of measured value. Within-laboratory reproducibility, estimated by standard deviation $\left(\mathrm{SD}_{\mathrm{R}}\right)$ and relative standard deviation $\left(\mathrm{RSD}_{\mathrm{R}}\right)$ given in Table 3 and Table 4 were considered acceptable.

The stability of the method, which was tested through the recovery, showed satisfactory results. The values for recoveries were found to be stable over the tested period, having in mind the Shewhart control chart (Fig. 3 and Fig. 4). These limits of the chart, reflect that the process operate as consistently as possible without fundamental changes.

The results obtained from the conducted monitoring for presence of aflatoxins and OTA in animal liver samples, showed presence of OTA in $12.45 \%$ of samples ( 37 out of 297 ). OTA was present in very low concentration range $(0.130-0.922 \mu \mathrm{g} / \mathrm{kg})$. The greater number of the samples $(87.55 \%)$ were 
with OTA concentration below LOD $(0.08 \mu \mathrm{g} / \mathrm{kg})$, although some studies $(14,15,22,23)$ showed higher value of OTA in pig tissues (more than $15.0 \mu \mathrm{g} / \mathrm{kg}$ ). We didn't find any sample with presence of aflatoxins. Although there isn't official MRL's for mycotoxins in animal tissues, the attention should be paid and regular monitoring for presence of mycotoxins should be organized.

\section{CONCLUSION}

It was confirmed, through the validation procedures, that the proposed methods are rapid, reliable, providing satisfactory recoveries (mean value for total aflatoxins was $78.10 \%$ and mean value for OTA was 93.34\%), with acceptable precision values in the range of $1.97-14.41 \%$ for all four aflatoxins and $3.76-8.31 \%$ for OTA, at three proposed concentration levels. The methods also showed high peak selectivity and low values for LOD and LOQ. All the validation parameters are in accordance to the requirements of European regulation and all of them indicate that those methods are suitable for the determination of aflatoxins and OTA in animal liver. The methods were found to be applicable to determine significantly low concentration of proposed mycotoxins. The overall overview in a period of six years, showed no significant contamination in liver samples in Republic of North Macedonia. However, regular aflatoxins and OTA monitoring plan in animal liver is highly recommended.

\section{CONFLICT OF INTEREST}

The authors declared that they have no potential conflict of interest with respect to the authorship and/or publication of this article.

\section{ACKNOWLEDGEMENTS}

This research was supported by the Faculty of Veterinary Medicine, Ss. Cyril and Methodius University in Skopje.

\section{AUTHORS' CONTRIBUTION}

BSD conducted the validation, analyses, interpretation of the results and she wrote the manuscript. EDS and ZHM supervised the laboratory work and they corrected the manuscript. RU and KB supervised the conduction of validation and participated in the interpretation of results. AA conducted the laboratory work. DJ organized the laboratory work and corrected the manuscript.

\section{REFERENCES}

1. European Food Safety Authority (EFSA). (2006). Opinion of scientific panel on contaminants in food chain on a request from the commission related to ochratoxin A in food. EFSA J. 365, 1-56. https://doi.org/10.2903/j.efsa.2006.365

2. European Food Safety Authority (EFSA). (2004). Opinion of scientific panel on contaminants in food chain on a request from the commission related to ochratoxin A as undesirable substance in animal feed. EFSA J. 101, 1-36. https://doi.org/10.2903/j.efsa.2004.101

3. Binder, E.M., Tan, L.M., Chin, L.J., Handl, J., Richard, J. (2007). Worldwide occurrence of mycotoxins in commodities, feeds and feed ingredients. Anim Feed Sci Technol. 137, 265-282. https://doi.org/10.1016/j.anifeedsci.2007.06.005

4. Scientific Cooperation (SCOOP) Task Reports. (2002). Task 3.2.7. Assessment of dietary intake of ochratoxin A by the population of EU member states. 27, Italy, 2002.

http://ec.europa.ec//food/fs/scoop/3.2.7_en.pdf

5. Sharman, M., Gilbert, J. (1991). Automated aflatoxin analysis of foods and animal feeds using immunaffinity column clean-up and highperformance liquid chromatographic determination. J Chromatogr. 543, 220-225. https://doi.org/10.1016/S0021-9673(01)95771-1

6. Zinedine, A., Juan, C., Soriano, J.M., Moltó, J.C., Idrissi, L., Mañes, J. (2007). Limited survey for the occurrence of aflatoxins in cereals and poultry feeds from Rabat, Morocco. Int J Food Microbiol. 115, 124-127.

https://doi.org/10.1016/j.ijfoodmicro.2006.10.013 PMid:17218031

7. Ibáñez-Vea, M., Martinez, R., Gonzalez-Peñas, E., Lizarraga, E., Lopez de Cerain, A. (2011). Co-occurrence of aflatoxins, ochratoxin $\mathrm{A}$ and zearalenone I breakfast cereals from Spanish market. Food Control. 22, 1949-1955. https://doi.org/10.1016/j.foodcont.2011.05.008

8. Stojanovska-Dimzoska, B., Hajrulai-Musliu, Z., Dimitrieska-Stojkovic, E., Uzunov, R., Angeleska, A., Jankuloski, D. (2015). Co-occurrence of aflatoxins, ochratoxin A and zearalenon in feed components determined by liquid chromatography with fluorescence detection. 2nd International VETistanbul Group Congress April 2015, St. Petersburg, Book of Abstracts, p. 744. 
9. Skarkova, J., Ostry, V., Malir, F., Roubal, T. (2013). Determination of ochratoxin A in food by high performance liquid chromatography. Anal Lett. 46(10): 1495-1504.

https://doi.org/10.1080/00032719.2013.771266

10. Bonerba, E., Ceci, E., Balzareti, C., Vallone, L., Crescenzo, G., Di Pinto, A., Celano, G.V., Tantillo, G., Bozzo, G. (2017). Ochratoxin A detection by HPLC-FL in processed baby foods. J Nephrol Ther. 7(4): 1000301.

11. Corcuera, L.A., Ibáñez-Vea, M., Vettorazzi, A., Gonzalez-Peñas, E., Lopez de Cerain, A. (2011). Validation of UHPLC-FLD analytical method for the simultaneous quantification of aflatoxin B1 and ochratoxin $\mathrm{A}$ in rat plasma, liver and kidney. J Chromatogr. B. 879, 2733-2740.

https://doi.org/10.1016/j.jchromb.2011.07.039 PMid:21868292

12. Tavčar-Kalcher, G., Vrtač, K., Pestevšek, U., Vengušt, A. (2007). Validation of the procedure for the determination of aflatoxin B1 in animal liver using immunoaffinity columns and liquid chromatography with postcolumn derivatisation and fluorescence detection. Food Control. 18, 333-337.

https://doi.org/10.1016/j.foodcont.2005.10.016

13. Küçükçakan, B., Stojanovska-Dimzoska, B., Hajrulai-Musliu, Z., Dimitrieska-Stojkovic, E., Uzunov, R., Davcheva, K. (2016). Determination of ochratoxin A in cattle lever by HPLC-FD method. Kafkas Univ Vet Fak Derg. 22(1): 1-5.

14. Jorgensen and Petersen (2002). Content of ochratoxin A in paired kidney and meat samples from healthy Danish slaughter pigs. Food Addit Contam. 19(6): 562-567.

https://doi.org/10.1080/02652030110113807 PMid:12042022

15. Ceci, E., Bozzo, G., Bonerba, E., Di Pinto, A., Tantillo, M.G. (2007). Ochratoxin A detection by HPLC in target tissues of swine and cytological and histological analysis. Food Chem. 105, 364-368. https://doi.org/10.1016/j.foodchem.2006.12.019
16. Commission of the European Communities. (2002). Commission Decision of 12 August 2002 implementing Council Directive 96/23/EC concerning the performance of analytical methods and the interpretation of results (2002/657/EC). Off J Eur Union. L 2218-2236.

17. Commission of the European Communities. (2006). Commission Regulation (EC) No 401/2006 of 23 February 2006 laying down the methods of sampling and analysis for the official control of the levels of Mycotoxins in foodstuffs. Off J Eur Union. L 70, $12-34$.

18. AOAC Official Method 982.24. Aflatoxin B1 and M1 in liver (AOAC 18th Edition).

19. ISO 16050:2003 Foodstuffs - determination of aflatoxin B1 and the total content of aflatoxins B1, B2, G1 and G2 in cereals, nuts and derived products - high-performance liquid chromatographic method.

20. Taylor, B., Kuyatt, C. (1994). Guidelines for evaluating and expressing the uncertainty of NIST Measurement Results. In: NIST Editorial Review Boards. NIST Technical Note. 1297, 1-20. https://doi.org/10.6028/NIST.TN.1297

21. Dragaci, S., Grosso, F.R., Bire, R., Fremy, M., Coulon, S. (1999). A French monitoring programme for determining ochratoxin A occurrence in pig kidneys. Nat Toxins. 7, 167-173.

https://doi.org/10.1002/(SICI)1522-7189(199907/08)7: 4<167::AID-NT55>3.0.CO;2-Q

22. Milicevic, D., Juric, V., Stefanovic, S.M., Veskovic-Moracanin, S.V., Jankovic, S. (2009). Analysis of ochratoxin A in pig tissues using high pressure liquid chromatography (HPLC) and liquid chromatography tandem mass spectrometry as confirmative method. Proc Nat Sci Matica Srpska Novi Sad. 117, 51-61. https://doi.org/10.2298/ZMSPN0917051M

23. Milicevic, D., Stefanovic, S., Jankovic, S., Radicevic, T. (2012). Risk analysis and exposure assessment of ochratoxin A in Serbia. Vet World. 5, 412-416. https://doi.org/10.5455/vetworld.2012.412-416 